\title{
Comparative of Feasibility Study Between Diesel Mechanical Propulsion System and Combination of Diesel Engine and Electric Motor Propulsion System on Offshore Patrol Vessel (OPV) $80 \mathrm{~m}$
}

\author{
Eddy Setyo Koenhardono ${ }^{1, *}$, and Amiadji ${ }^{1}$ \\ ${ }^{1}$ Institut Teknologi Sepuluh Nopember, Departemen Teknik Sistem Perkapalan
}

\begin{abstract}
The modern offshore patrol vessel is designed to carry out various missions in the management of economic exclusion zones, thus having some speed of service. For example, the speed for slow patrol is 10 knots, regular patrols 18 knots and chasing 22 knots. This condition requires a flexible propulsion system, which is combination of mechanical and electrical propulsion system. The application of this propulsion system to the OPV can increase the load factor of the propulsion system, resulting in lower fuel consumption than when using a mechanical propulsion system. Based on feasibility analysis results, the choice of combination of mechanical and electrical propulsion system is more advantageous than mechanical propulsion system, although investment and maintenance cost is higher. Therefore, patrol boats should use combination of mechanical and electrical propulsion system.
\end{abstract}

\section{Introduction}

Offshore patrol vessels (OPV) have multiple functions, namely military and civilian. Therefore, OPV's weapon system is not as sophisticated as the KCR ship. In the framework of development of Minimum Essential Force (MEF II), the government plans to build 2 OPV vessels of $80 \mathrm{~m}$. The type of OPV vessel propulsion offered by Dutch DAMEN and French DNCS uses a mechanical propulsion system. [1]

The OPV vessel has operational areas in the exclusive economic zone (EEZ) to monitor illegal activities, such as infiltration of foreign troops, illegal fishing, pirate handling, smuggling, and illegal immigrants, handling of marine accidents / oil spills, border controls and other similar activities [2]. Based on this function, the OPV vessel operates under various speed conditions, i.e. surveillance (10 knots), patrols (18 knots), and interception (22 knots).

The CODAE propulsion system is a dynamic combination of diesel mechanic propulsion (DMP) system and diesel electric propulsion (DEP) systems. This system has four propulsion modes: shaft motor, shaft generator, mechanical, and booster modes [3-9]. These various propulsion modes could adapt to meet the requirement of the various OPV $80 \mathrm{~m}$ 's operation condition. Such propulsion system is worth considering to be applied to the OPV $80 \mathrm{~m}$ due the operational flexibility it offers.

This paper presents a configuration layout and specification of the CODAE propulsion system applied as well as the comparison between the DMP and CODAE systems in terms of both technical and economic aspects.

* Corresponding author: eddy-koen@its.ac.id 


\section{The CODAE Propulsion System}

Basically, the propulsion system used on ships can be classified into three types, namely mechanical, electrical and combination of them. A propulsion system is a combination of mechanical and electrical propulsion systems, that is called by hybrid propulsion system or combination of diesel mechanic or electric (CODAE) propulsion system. Therefore, the CODAE system can operate as a mechanical, electrical or mechanical and electrical combination system [3-9]. Selection of operating mode on a CODAE propulsion system is adjusted to the existing propulsion power requirement, so that it can maintain to operate at optimal conditions.

A CODAE propulsion system that also uses shaft generator is referred to as a CODAE propulsion system, therefore the system has four operational modes. The four operational modes are electric, power take off/shaft generator, mechanic and hybrid (CODAE) modes. Where the selection of suitable mode is based by fluctuations in the propulsion power and electric power are needed.[4] Figure 1 shows the difference between the mechanical propulsion system and CODAE propulsion system, where the difference lies in the shaft generator / motor and hybrid shaft generator (HSG) drive.

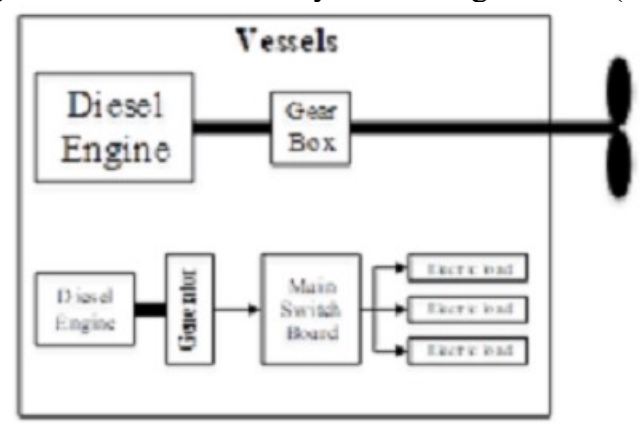

a. Diesel Mechanical Propulsion system

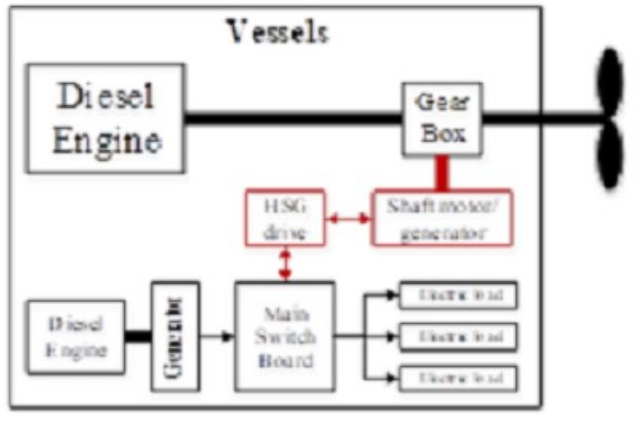

b. CODAE propulsion system

Fig 1. DMP and CODAE propulsion system [6]

In general, OPV patrol boats use diesel mechanical propulsion systems, due to their simplicity and reliability. Since OPV ship missions have been increasingly variable, the conventional propulsion system is less suitable. Therefore, the CODAE propulsion system is one of the replacement candidates, in addition to the electrical propulsion system. As mentioned in the above paragraph, the mechanical propulsion system can be a CODAE propulsion system in the presence of a generator / motor shaft and HSG controller.

\section{The Feasibility Study of Ship Propulsion System}

The feasibility study is a major study to decide whether a project is implemented, suspended or terminated. The review is conducted by reviewing various aspects, such as legality aspect, technical aspect, marketing, social economy, economics and management and finance. In this paper, the comparison of feasibility analysis between the use of mechanical propulsion system and CODAE on the OPV patrol boat is only viewed from the technical and economic aspect. The purpose of the technical aspect is determination of propulsion and electric system configuration for both DMP and CODAE for the OPV $80 \mathrm{~m}$. The economic aspect includes comparing total investment cost, fuel consumption cost, and maintenance cost between the use of both propulsion systems. The result of comparison is a break even point (break event point). 
Tables 1. Operational Profile of OPV $80 \mathrm{~m}$

\begin{tabular}{|c|l|c|c|c|c|}
\hline No. & $\begin{array}{c}\text { Operation } \\
\text { conditions }\end{array}$ & $\begin{array}{c}\text { Vs } \\
{[\mathrm{knot}]}\end{array}$ & $\begin{array}{c}\text { Propulsion } \\
\text { Power }(\mathrm{kW})\end{array}$ & $\begin{array}{c}\text { Electrical Power } \\
(\mathrm{kW})\end{array}$ & $\begin{array}{c}\text { Duration } \\
{[\text { hour/year] }}\end{array}$ \\
\hline 1 & At port & - & 0 & 873 & 3504 \\
\hline 2 & Loitering & 10 & 645 & 1021 & 1577 \\
\hline 3 & Patrol & 18 & 3921 & 1110 & 2102 \\
\hline 4 & Interception & 22 & 7637 & 1129 & 1577 \\
\hline
\end{tabular}

\subsection{Technical Aspect}

The configuration of OPV's propulsion system is obtained based on OPVs' operational profile. The OPV's operation profile is as shown in Table 1, there are four operation conditions with different speed. In accordance with the need for propulsion power and electrical power under each operating condition of the vessel, the engine propeller matching (EPM) analysis, and generator capacity analysis are performed. There are three main purposes of EPM analysis, first, the full power of the main engine can be developed or almost full power. Secondly, the propulsion plant will function satisfactorily in all designs and design conditions. Third, the main engine operates on the best fuel consumption. The result of both analyses for DMP and CODAE propulsion system is presented in Table 2 .

Tables 2. Component of DM and CODAE Propulsion System

\begin{tabular}{|c|c|c|c|}
\hline No & Component & DM Propulsion Systems & CODAE Propulsion System \\
\hline 1 & Main Engine & $\begin{array}{l}2 \text { MTU 20V4000 M93L, 4300kW, } \\
2100 \mathrm{rpm}\end{array}$ & $\begin{array}{l}2 \text { MTU 20V4000 M73L, 3600kW, } \\
2050 \mathrm{rpm}\end{array}$ \\
\hline 2 & $\begin{array}{l}\text { Auxiliary } \\
\text { Engine }\end{array}$ & $\begin{array}{l}4 \text { CAT C18 ACERT, } 450 \mathrm{kWe}, 1500 \\
\text { rpm, 380VAC. }\end{array}$ & $\begin{array}{l}4 \text { KOHLER KD800-YF, } 720 \mathrm{kWe} / 900 \\
\text { Kva, } 1500 \text { rpm, 400VAC. }\end{array}$ \\
\hline 3 & Propeller & $\begin{array}{l}2 \begin{array}{l}\text { Wageningen } \mathrm{B} 4.65, \mathrm{D}=1,83 \mathrm{~m}, \mathrm{P} / \mathrm{D} \\
0.852, \eta_{0}=0.569\end{array}\end{array}$ & 2 СРР В $4.55, \varnothing 1,6 \mathrm{~m}, P / D$ 0,5-1,4 \\
\hline 4 & Gear box & 2 Single input \& output, ratio $3: 1$ & \begin{tabular}{|l}
2 ZF 24060 D PTI, $4615 \mathrm{~kW} / 2050 \mathrm{rpm}$, \\
single input \& double output $(1: 1 \&$ \\
2.577:1).2650 kg
\end{tabular} \\
\hline 5 & $\begin{array}{l}\text { Shaft motor/ } \\
\text { generator }\end{array}$ & & $\begin{array}{l}2 \text { ABB M3BP } 355 \mathrm{SMC} 4,400 \mathrm{VAC}, \\
616 \mathrm{~A}, 355 \mathrm{~kW}, 50 \mathrm{~Hz}, 1487 \mathrm{rpm}, \\
2280 \mathrm{Nm}\end{array}$ \\
\hline 6 & HSG drive & & $\begin{array}{c}2 \text { ABB ACS850-04-650A-5, } 3 \text { phase, } \\
355 \mathrm{~kW}, 380 \sim 500 \mathrm{VAC}, 650 \mathrm{~A}\end{array}$ \\
\hline
\end{tabular}

\subsection{Economic Aspect}

\subsubsection{Investment Cost}

The investment cost of a propulsion ship system OPV $60 \mathrm{~m}$ is the cost that must be incurred by the ship owner to build or modify the ship's propulsion system. This cost includes the components of the configuration of each type of propulsion system. The components of the mechanical propulsion system and CODAE refer to Table 2, which consists of main engine, auxiliary engine, propeller, gear box, generator shaft / motor and HSG drive.

Generally, the investment cost of each component of the ship propulsion system is based on the power capacity. For investment cost of diesel engine as main driver of ship besides influenced by big power factor, hence congress type conguration and bore size also have an effect. For example, the investment cost of an inline diesel engine is higher than that of a V-line diesel engine. In addition, the investment cost of V-line diesel engines decreased along with the increase in bore size. Table 3 summarizes the prices of ship propulsion system components. 
Tables 3. Comparasion of investment cost between DMP and CODAE Propulsion System

\begin{tabular}{|c|l|rr|rr|}
\hline No & \multicolumn{1}{|c|}{ Component } & \multicolumn{2}{c|}{ DMP Propulsion Systems } & \multicolumn{2}{c|}{ CODAE Propulsion System } \\
\hline 1 & Main Engine & $€$ & $2.924 .000,-$ & $€$ & $2.448 .000,-$ \\
\hline 2 & Auxiliary Engine & $€$ & $720.000,-$ & $€$ & $1.152 .000,-$ \\
\hline 3 & Propeller & $€$ & $860.000,-$ & $€$ & $791.000,-$ \\
\hline 4 & Gear box & $€$ & $598.000,-$ & $€$ & $609.500,-$ \\
\hline 5 & Shaft motor/generator & & & $€$ & $95.850,-$ \\
\hline 6 & HSG drive & & & $€$ & $56.000,-$ \\
\hline \multicolumn{2}{|c|}{ Total of investment cost } & $€$ & $5.102 .000,-$ & $€$ & $5.133 .720,-$ \\
\hline
\end{tabular}

\subsection{Fuel Consumption Cost}

In general, the largest component of ship operating costs is fuel costs (Wijayanto, 2011). One of the factors affecting the fuel cost of a ship is load factor of main engine and auxiliary engine. Operation of main engines and auxiliary engines at high load factor conditions have lower SFOC than operating at low load factor. OPV vessels operate at some service speed according to their mission, so the load factor varies. The comparison of fuel consumption between the application of mechanical propulsion system and CODAE according to the operational profile of OPV $80 \mathrm{~m}$ in Table 4.

Tables 4. Fuel consumption based on OPV profile

\begin{tabular}{|l|c|c|c|c|c|c|}
\hline \multirow{2}{*}{$\begin{array}{c}\text { Operation } \\
\text { mission }\end{array}$} & \multirow{2}{*}{$\begin{array}{c}\text { Speed } \\
\text { (knot) }\end{array}$} & $\begin{array}{c}\text { Duration } \\
\text { (hour/year) }\end{array}$ & \multicolumn{2}{|c|}{ DMP propulsion system } & \multicolumn{2}{c|}{ CODAE propulsion system } \\
\hline Harbouring & - & 3500 & - & 998 ton & - & 645 ton \\
\hline Surveillance & 10 & 1550 & 288 ton & 445 ton & - & 571 ton \\
\hline Patroling & 18 & 2100 & 1836 ton & 593 ton & 2040 ton & 245 ton \\
\hline Chasing & 22 & 1550 & 2212 ton & 445 ton & 2204 ton & 605 ton \\
\hline \multicolumn{3}{|c|}{ Total of fuel consumption } & \multicolumn{2}{|c|}{6817 ton/year } & \multicolumn{2}{c|}{6309 ton/year } \\
\hline
\end{tabular}

\subsection{Maintenance Cost}

The cost of maintaining a patrol boat propulsion system includes all costs incurred for maintenance and repair of the propulsion system, including maintenance costs of the main engine, diesel generator set, CPP, gearbox, frequency converter, and generator / motor shaft. Maintenance cost of each component is primary data obtained through direct interview with the expert from the engine distribution's company, shipyard, and shipping company as owner and / or ship operator. The result of interview may be tabulated in Table 5 and Table 6.

Table 5. Maintenance and spare part replacement cost of diesel motor

\begin{tabular}{|c|c|c|c|}
\hline Diesel motor & $\begin{array}{c}\text { Type of } \\
\text { maintenance }\end{array}$ & Maintenance cost & $\begin{array}{c}\text { Replacement cost of } \\
\text { spare part }\end{array}$ \\
\hline \multirow{2}{*}{$\begin{array}{l}\text { Main engine: } \\
3440 \mathrm{~kW}, 2100 \mathrm{rpm}\end{array}$} & Top Overhaul & Rp $960.000 .000,-$ & Rp 3.602.000.000,- \\
\hline & General Overhaul & Rp 1.601.000.000,- & Rp 6.003.000.000,- \\
\hline \multirow{2}{*}{$\begin{array}{l}\text { Diesel generator: } \\
565 \mathrm{~kW}, 1500 \mathrm{rpm}\end{array}$} & Top Overhaul & Rp $143.000 .000,-$ & Rp $792.000 .000,-$ \\
\hline & General Overhaul & 187.000.000,- & Rp 1.322.000.000,- \\
\hline \multirow{2}{*}{$\begin{array}{l}\text { Diesel generator: } \\
846 \mathrm{~kW}, 1500 \mathrm{rpm}\end{array}$} & Top Overhaul & Rp $\quad 175.000 .000,-$ & Rp 1.189.000.000,- \\
\hline & General Overhaul & Rp $\quad 292.000 .000,-$ & Rp 1.983.000.000,- \\
\hline
\end{tabular}


Tabel 6. Maintenance cost of electric motor based on spesification and the level

\begin{tabular}{|c|c|c|c|}
\hline $\begin{array}{l}\text { Spesification of } \\
\text { electric motor }\end{array}$ & Level & Hour operating & Recondition cost \\
\hline \multirow{4}{*}{$\begin{array}{l}400 \mathrm{~kW} \\
400 \mathrm{Volt} \\
1500 \mathrm{rpm} ; \\
50 \mathrm{~Hz}\end{array}$} & L1 & 10.000 & Rp $6.500 .000,-$ \\
\hline & L2 & 20.000 & Rp $\quad 6.500 .000,-$ \\
\hline & L3 & 40.000 & Rp 36.000.000,- \\
\hline & L4 & 80.000 & Rp 68.000.000,- \\
\hline \multirow{4}{*}{$\begin{array}{l}700 \mathrm{kWe} \\
400 \mathrm{Volt} \\
1500 \mathrm{rpm} \\
50 \mathrm{~Hz}\end{array}$} & L1 & 10.000 & Rp 9.500.000,- \\
\hline & L2 & 20.000 & Rp 9.500.000,- \\
\hline & L3 & 40.000 & Rp 57.000.000,- \\
\hline & L4 & 80.000 & Rp 89.000.000,- \\
\hline
\end{tabular}

The amount of labor honor for the maintenance of one unit of perporosan system based on field data in a shipyard in Surabaya is Rp. 23.343.750, -. In general, shaft system maintenance should replace three packings, where the price per unit is Rp 2.500.000, -. This replacement is done when the ship does General Overhaul 5 years.

\section{Break Event Point}

Break Even Point (BEP) between mechanical and hybrid propulsion systems is a point where the sum of investment costs and operational costs are both the same. The length of time to reach Break Even Point can be used to make changes to the ship propulsion system or not. Break Even Point calculations require basic calculation components such as the following:

1. Fixed Cost. In the ship propulsion system investment, this component is a fixed or constant cost.

2. Variable Cost. In the ship propulsion system investment, the dynamic cost components depend on the ship's operational profile. If the ship's operational length and speed increase, then the variable cost increases. Examples of these costs are the cost of fuel consumption, maintenance costs and replacement cost of spare parts.

3. Selling Price. This component in the ship propulsion system changes is an advantage that can be obtained due to changes in the propulsion system.

In this analysis, there are only two component of BEP to be considered, that is fixed and variable costs. The fixed cost is investment cost of the propulsion system. The investment cost includes purchasing and installation costs of components of both the propulsion systems. Variable cost includes fuel consumption costs dan all maintenance cost, both costs are time dependent. Figure 2 is the result of BEP analysis, where the BEP can be reach less than one year.

\section{Conclusions}

As shown in Table 2, the main differences between DMP and CODAE for OPV's 80 are reductions of main engine power and increase the diesel generator power capacity. The use of electric motors as the propulsion of ships under surveillance conditions can reduce the fuel consumption is very large. Operation of diesel motors on low load factors $(15 \%)$ results in high fuel consumption $(300 \mathrm{gr} / \mathrm{kWh})$. The difference in investment cost between DMP and CODAE propulsion system is not much different, compared to when using electric propulsion system. Therefore, the BEP between using a mechanical propulsion system into a CODAE propulsion system can be achieved in less than a year. Therefore, in the future, the use of CODAE propulsion systems on patrol boats is highly recommended.

This work was financially supported by PTNBH 2016 of Institut Teknologi Sepuluh Nopember. 


\section{References}

[1] A. D. Firmansyah, et al.,"Perancangancontrollable pitch propeller pada kapal offshore patrol vessel 80 (OPV80)," Jurnal Teknik ITS, vol. 1, no. 1, pp. G230 - G231, Sept. 2012.

[2] M. J. Underwood, "Patrol boats: aworldmarket overview,"Marine Technology, vol. 33, no. 2, pp. $101-107$, Apr. 1996

[3] Koenhardono, E.S., "Neural Network-Based Engine Propeller Matching (NN-EPM) for Trimaran Patrol Ship", in Applied Mechanics and Materials Vol. 493 (2014) pp 388394.

[4] D. Wahyudi, "Hybrid Propulsion Sistem (DMP \& DEP) for Trimaran Type Fast Patrol Boat", SENTA Conference, Surabaya 2009.

[5] Koenhardono, E.S., "Perencanaan Konfigurasi Sistem Propulsi Hybrid Pada Kapal Patroli Trimaran", SENTA Conference, Surabaya 2012.

[6] B. Kwasieckyj, "Hybrid propulsion systems: efficiency analysis and design methodology of hybrid propulsion systems," TU Delft, SDPO.13.008.m, March 2013.

[7] Koenhardono, E.S., "Selection of propulsion systems for naval patrol trimaran vessels between the hybrid shaft generator and mechanical propulsion system", SENTA International Conferenece, Surabaya, 2016.

[8] Koenhardono, E.S., "Applications of Hybrid Propulsion System on Trimaran Tourist Vessels that Reliable and Environmental Friendly", SENTA International Conference, Surabaya 2017.

[9] Koenhardono, E.S., "The Study of the Application of Hybrid Propulsion System on OPV with Controllable Pitch Propellers”, IJMEIR, Vol. 1(4), Sept. 2017. 346-354. 